\title{
Isolation and Identification of Most Prevailing Fungal Diseases of Wheat and Maize in Tehsil Havelian, District Abbottabad
}

\author{
Khadija Sardar ${ }^{1}$, Zishan Gul ${ }^{2 *}$ and Ghulam Mujtaba Shah ${ }^{\mathbf{1}}$ \\ ${ }^{1}$ Department of Botany, Hazara University Mansehra, Pakistan \\ ${ }^{2}$ Hazara Agriculture Research Station, Abbottabad, Pakistan \\ *Corresponding Author: Zishan Gul, Hazara Agriculture Research Station, \\ Abbottabad, Pakistan.
}

Received: May 22, 2021

Published: July 09, 2021

(C) All rights are reserved by Zishan Gul., et al.

\begin{abstract}
The present study was designed to investigate fungal diseases of wheat and maize crops of Tehsil Havelian, District Abbottabad, Pakistan. In this study seven fungal pathogens (Puccinia triticina, Ustilago tritici, Alternaria triticina, Drechslera tritici repentis, Fusarium gramenarium, Cladosporium herbarum, Curvularia lunata) causing leaf rust, Smut, Alternaria leaf blight, Tan spot/yellow spot, Fusarium head blight, Black point in wheat and four fungi (Bioplaris maydis, Alternaria alternata, Curvularia lunata and Colletotrichum graminicola) causing Sourthen leaf blight, Alternaria leaf blight, Curvularia leaf spot and Anthracnose leaf blight in maize were isolated and identified on the basis of cultural characteristics and micrometry. In wheat samples Puccinia recondita and Alternaria triticina were most prevalent pathogens isolated in all ten sampling locations and showed maximum percent incidence of $73.33 \%$ and 90\%, respectively. While Curvularia lunata was isolated from only one location Pangran with maximum incidence of $6.67 \%$. Similarly in maize samples Alternaria alternata and Bipolaris maydis were dominated pathogens isolated in three locations Chamba, Sultanpur and Takia sheikhan with highest percent incidence $93.33 \%$ and minimum percent incidence was shown by Curvularia lunata i-e 3.33\% isolated from samples of six locations. All foliar samples of wheat and maize were found infected either singly or mixed infection. Single infection percentage was found higher as compared to mixed infection.
\end{abstract}

Keywords: Wheat; Maize; Fungal Diseases; Disease Incidence

\section{Introduction}

Wheat (Triticum aestivum) and maize (Zea mays) are two important cereal crops that belong to family poaceae. Wheat is the leading grain crop of Pakistan used as major food. Similarly, Maize is also the top most crops of the world according to its total production and in Pakistan after rice and wheat it is largest grown crop.

In 2018-19 Pakistan cultivates wheat on an area of 8,470 (000, hec) with a total production 25,195 milliones tonnes [1], while in
Khyber Pakhtunkhwa province total area of wheat was 739570 thousand hectares and total production was 1327580 million tonnes [2].

Production of wheat worldwide is effected by many factors, diseases are considered major yield stress. However, the production is highly constrained by fungal incited diseases which cause losses $15-20 \%$ in yield [3]. Among fungal diseases, foliar pathogens are considered most important to reduce average yield of cereal crops. The reduction in yield due to leaf blight recorded in India dur- 
ing 1998 and 1999 decreased the 1000 grain weight significantly from 1.2 to $26.1 \%$ [4]. Other important foliar diseases are rusts and smuts [5] which are present in almost every area of Pakistan where wheat is cultivated. During a survey of wheat fields in the surrounding areas of Islamabad in spring 2000 tan spot was found as great as spot blotch [6]. The other fungi isolated from wheat foliage in various areas of Punjab were Alternaria alternata, Bipolaris sorokiniana, Cladosporium spp, Helminthosporium spp. and Stemphylium spp [7].

Maize is also a major grain crop in world after wheat and rice. Maize is multipurpose cereal providing fuel and food to human beings, feed to animals and poultry, and fodder to livestock [8]. Maize covers $75 \%$ of the world food supplies and cultivated in all parts of the world. It is another cash and food crop of Pakistan where it was grown on an area of $1,318(000$, hec $)$ in $2018-19$ with a production of 6,309 million tones [1].

Maize is infected by different microbes causes a great food loss (30\% total production) in the world [9]. Global losses in maize due to diseases were recorded to be $9 \%$ in 2001-03. Stalk and ear rots, Gray leaf spot, Southern leaf blight, northern leaf blight, gray leaf spots and different kinds of rust are amongst main diseases of maize $[10,11]$.

Wheat and maize are major crops of Tehsil Havelian, District Abbottabad, Khyber Pakhtunkhwa Province. Tehsil Havelian lies in $34^{\circ} 05^{\prime} \mathrm{N}$ latitude and $73^{\circ} 16^{\prime} \mathrm{E}$ longitudes and is located on the Karakoram Highway about 15.5 kilometers south west of Abbottabad at 868 meter height above sea level. The area fall in subtropical humid zone with mild to warm temperature during April-May and September-October respectively; humid temperature in JuneJuly, and cool to mild temperature during November-February. The temperature rises up to $35^{\circ} \mathrm{C}$ during the mid-summer months and drops below $0^{\circ} \mathrm{C}$ during winter months.

No systematic work regarding isolation and identification of major fungal diseases of Wheat and Maize of Tehsil Havelian has been done so far, therefore present study was designed to diagnose the foliar fungal diseases of wheat and maize of Tehsil Havelian on the basis of characteristic symptoms in the field, microscopic slides and cultural characteristics, incidence percentage of isolated fungi and their presence as single or mixed infections.

\section{Materials and Methods}

\section{Sample collection}

Ten locations (Sultanpur, Chamba, Jangra, Pangran, Bandi Subkhan, Khokkar Maira, Langra, Takia Sheikhan, Diwal minhal, Sajjikot) in Tehsil Havelian (Figure 1) where wheat and maize are grown as major crops were selected and extensive survey was conducted during 2019. Total 300 samples of each crop i.e. wheat and maize were collected randomly from farmers field on the basis of disease symptoms following the ' $Z$ ' pattern as a sampling procedure [12]. Photography of disease symptoms and field diagnosis of diseases was made on the basis of physical observation of characterstic symptoms in the field at the time of sampling. A single sample consisted of leaves plucked from bottom, middle and top of plant showing symptoms and stored in labeled polyethylene zipper bags to indicate location, sample number and date of collection. The samples were brought to the laboratory at Hazara Agriculture research station Abbottabad (HARS) for isolation and identification of fungi associated with disease symptoms.

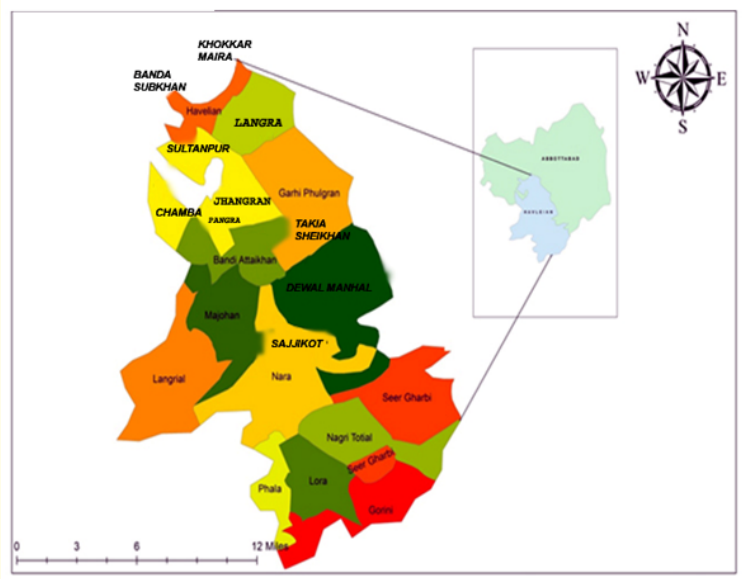

Figure 1: Map of Tehsil Havelian with sampling locations.

\section{Isolation of fungus}

Agar plate method was used for fungus isolation. Potato Dextrose Agar (PDA) media was prepared and autoclaved at $121^{\circ} \mathrm{C}$ at 15 psi pressure for 15 minutes. After autoclaving the PDA was poured @ 15 - $20 \mathrm{ml}$ per petridish of $9 \mathrm{~cm}$ diameter under sterilized laminar flow chamber. The samples showing disease symptoms were cut into small pieces. The pieces were first surface dis- 
infected with $3 \%$ sodium hypochlorite ( $\mathrm{NaOCl}$ ) solution for three minutes, washed three times with sterilized distilled water and placed on sterilized blotting paper to dry excess water. The samples were aseptically inoculated on PDA medium and incubated for seven days in growth chamber at $25^{\circ} \mathrm{C}$.

\section{Identification of fungi}

After incubation the morphology of fungal colonies were observed and microscopic slides were made from the cultures, identification was made by using morphological keys of Barnett and Hunter [13] and Eillis [14] and micrometery was also done for measuring conidial size. The isolated fungi were subcultured on potato dextrose agar in order to get pure culture.

The $\%$ incidence of individual fungus was calculated by using formula:

$\%$ incidence $=$

No. of samples infected with respective fungal species $\mathrm{x} 100$

Total number of samples

\section{Statistical analysis}

The recorded data on percent fungal incidence was subjected to analysis of variance (ANOVA) in Completely randomized design (CRD) with three replications per sample and the means were compared using least significance difference (LSD) test at $5 \%$ probability level. The statistical analysis was done using computer software Statistix 8.1.

\section{Results}

In this study a number of fungal pathogens and the respective diseases of wheat (Triticum aestivum) and maize (Zea mays) on the basis of symptoms and disease identification were made from the foliar samples collected from ten locations of Tehsil Havelian, District Abbottabad during March-May and August-October 2019, respectively.

\section{Fungi isolated from Wheat foliage}

The diseases diagnosed on the basis of visual symptoms and fungi isolated from wheat foliage were Leaf rust (Puccinia recondita), Smut (Ustilago tritici), Alternaria leaf blight (Alternaria triticina), Tan spot (Drechslera tritici repentis), Fusarium head blight (Fusarium graminearum) and black point (Cladosporium herbarum and Curvularia lunata).

\section{Leaf rust}

Leaf rust or brown rust (Puccinia recondita) is a fungal disease of wheat that was observed in all ten locations during sampling (Table 1 and 2). A significant difference ( $\mathrm{p} \leq 0.05)$ was observed among all the locations regarding \% incidence of Puccinia recondita (Table 1). Maximum incidence percentage-i.e. 73.33\% was observed in location Sultanpur followed by $53.33 \%$ in location Pangran whereas in location Langra its incidence was lowest (10\%) followed by location Diwal (13.33\%) (Table 1). The characteristic symptoms of leaf rust observed at the time of sampling in the field were Small, circular to oval orange coloured $1.5 \mathrm{~mm}$ long pustules on the upper side of leaves and on leaf sheath (Figure 2A). On some plants a mixture of orange and black lesions were observed. Each pustule contains thousands of urediospores, on some plants the uredinial stage turned into telial stage (Figure 2B) containing brown to black spores known as teliospores.

From the microscopic slides directly made from leaf samples collected from the field showing rust symptoms, uredospores were typically large orange-red, oval with thick rough outer wall, range from 10-20 $\mu \mathrm{m}$ (Figure 4B). Teliospores were brown to dark colour, 25-35 x 15-20 $\mu \mathrm{m}$ in size (Figure 4A). The characteristics of Puccinia recondita matched with those reported by $[13,14]$.

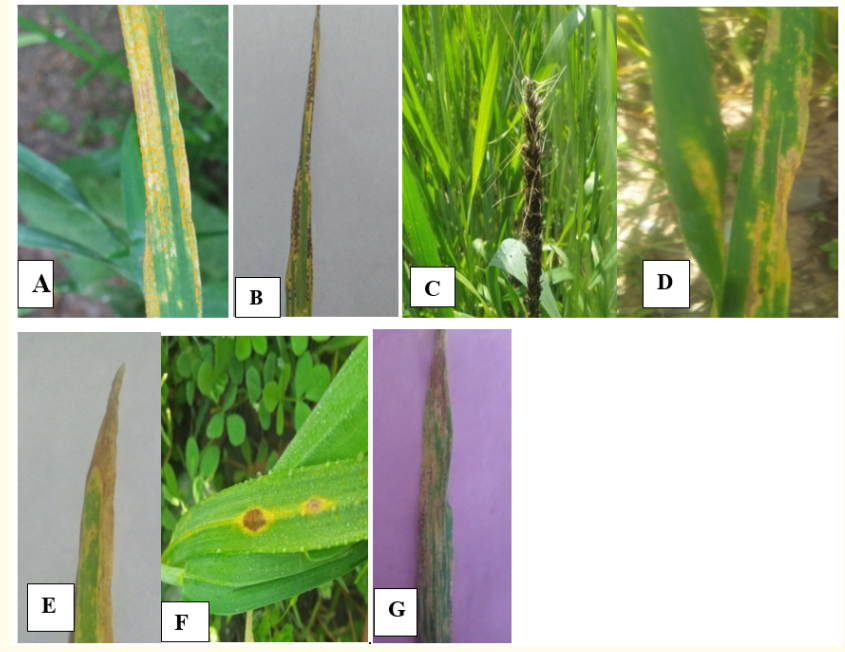

Figure 2: Characteristics symptoms of wheat Leaf rust $(A, B)$; Loose Smut (C); Alternaria Leaf Blight (D,E); wheat Tan Spot $(\mathrm{F}, \mathrm{G})$ in wheat Field. 

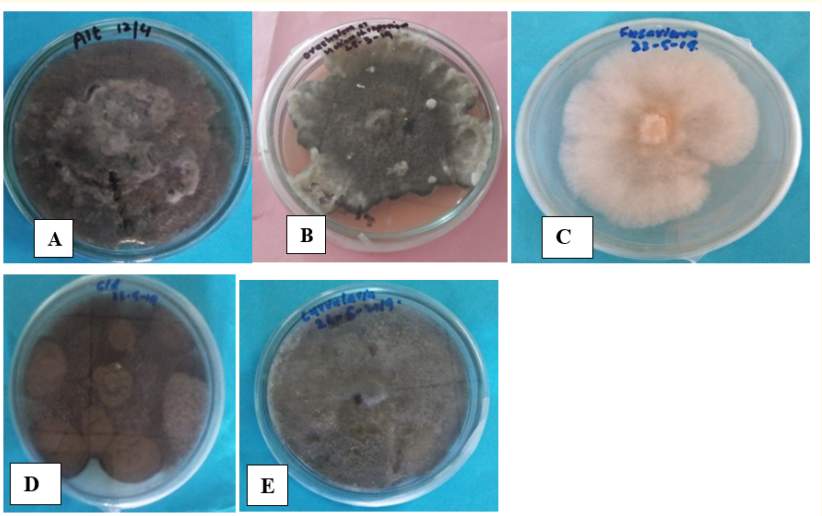

Figure 3: Pure cultures of fungi isolated from wheat foliar samples on PDA after seven days of incubation at $25^{\circ} \mathrm{C}$; Alternaria triticina (A); Drechslera tritici repentis (B); Fusarium graminearum (C); Cladosporium herbarum (D); Curvularia lunata (E).
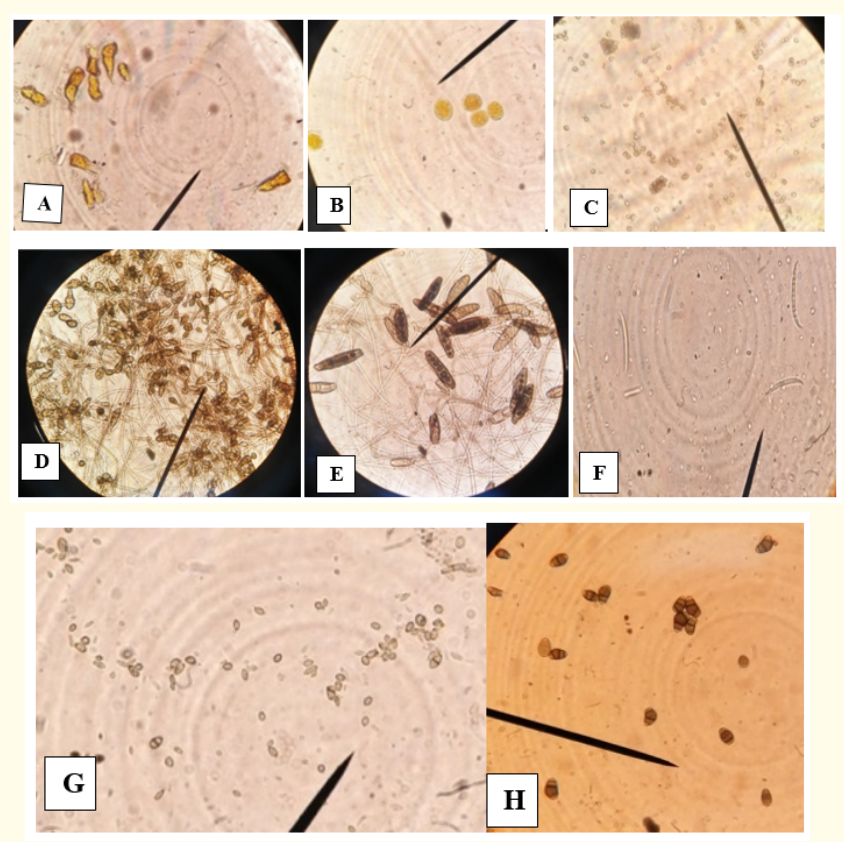

Figure 4: Teliospores (A) and Urediospores (B) of Puccinia recondita; conidia of Ustilago tritici (C); conidia of Alternaria triticina (D); Conidia of Drechslera tritici repentis (E); Conidia of Fusarium graminearum (F); Conidia of Cladosporium herbarum (G); Conidia of Curvularia lunata $(\mathrm{H})$ at $400 \mathrm{X}$ Magnification.
Loose smut

The causing agent of loose smut is Ustilago tritici and during sampling the loose smut symptoms were recorded in four locations Chamba, Jangra, Pangran and Sajikot with maximum fungal incidence of $23.33 \%$ in location Jangra while minimum (10\%) incidence in location Sajikot (Table 1). The disease can be identified easily at the time of heading. The infected head showed black sooty fungal spore masses instead of normal grains. All the grains in a smutted head were completely transformed to black powder (Figure 2C).

Conidia of Ustilago tritici were spherical to subglobose, darkly pigmented, brown in colour (Figure 4C), size ranges from 7.5 - 12.5 $\mu \mathrm{m}$. These characteristics of Ustilago tritici matched with those reported by $[13,14]$.

\section{Leaf blight}

The wheat leaf blight caused by Alternaria triticina was recorded from all the ten sampling locations (Table 1 and 2). The greatest $\%$ incidence of Alternaria triticina i.e. 90\% was recorded in location Langra followed by Dewal (83.33\%) (Table 1). Its characteristic symptoms on wheat observed during sampling were small, elongated colourless lesions appeared on the leaves which with the passage of time became dark brown to grey surrounded by chlorotic halo. These lesions differ in size reaching a diameter of $1 \mathrm{~cm}$ or more (Figure 2D and 2E). The disease first appeared on lower most leaves and gradually spread to the upper leaves.

The colony of Alternaria triticina on PDA was black to brown colour with smooth and entire margins (Figure 3A). Conidia were acrogenous, irregularly elliptical, both ends circular or ellipsoid and slowly tapering into a beak. Spores were pale brown to olive, which become darkish with time having 3-4 transverse and 1 longitudinal septa; length including beak was 27.5-52.5 $\mu \mathrm{m}$, width 10-17.5 $\mu \mathrm{m}$ (Figure 4D). These characteristics of Alternaria triticina resembles with those reported by $[13,14]$.

\section{Tan spot}

The prevalence of Tan spot of wheat also known as yellow leaf spot caused by fungus Drechslera tritici repentis (anamorph) or Pyrenophora tritici-repentis (telomorph) was lowest among all the isolated fungi and showed \% incidence of 3.33\% in only three locations (Table 1). Lesions first appeared as lens-shaped tan blotches with dark center surrounded by yellow border giving it a distinc- 


\begin{tabular}{|c|c|c|c|c|c|c|c|}
\hline \multirow[b]{2}{*}{ Location } & \multicolumn{7}{|c|}{$\%$ incidence of fungal pathogens } \\
\hline & $\begin{array}{l}\text { Puccinia } \\
\text { recondita }\end{array}$ & $\begin{array}{c}\text { Ustilago } \\
\text { tritici }\end{array}$ & $\begin{array}{l}\text { Alternari- } \\
\text { atriticina }\end{array}$ & $\begin{array}{c}\text { Fusarium } \\
\text { graminearum }\end{array}$ & $\begin{array}{c}\text { Drechslera } \\
\text { tritici-repentis }\end{array}$ & $\begin{array}{l}\text { Cladosporium } \\
\text { herbarum }\end{array}$ & $\begin{array}{c}\text { Curvularia } \\
\text { Iunata }\end{array}$ \\
\hline Sultanpur & $73.33 a$ & $0 \mathrm{c}$ & $23.33 \mathrm{e}$ & 0c & $3.33 \mathrm{a}$ & $0 \mathrm{c}$ & $0 \mathrm{~b}$ \\
\hline Chamba & $43.33 b$ & $16.67 \mathrm{ab}$ & $40 \mathrm{cde}$ & $0 \mathrm{c}$ & $0 \mathrm{a}$ & $0 \mathrm{c}$ & $0 \mathrm{~b}$ \\
\hline Jangra & $36.67 b$ & $23.33 \mathrm{a}$ & 40 cde & $0 \mathrm{c}$ & $0 \mathrm{a}$ & $0 \mathrm{c}$ & $0 \mathrm{~b}$ \\
\hline Pangran & $53.33 \mathrm{ab}$ & 13.33ab & 30de & $0 \mathrm{c}$ & $0 \mathrm{a}$ & $0 \mathrm{c}$ & $6.67 a$ \\
\hline Banda & $40 \mathrm{~b}$ & 0c & $46.67 \mathrm{~cd}$ & $3.33 c$ & $0 \mathrm{a}$ & 23.33ab & $0 \mathrm{~b}$ \\
\hline Khokkar Maira & $33.33 \mathrm{bc}$ & 0c & $50 \mathrm{~cd}$ & $30 \mathrm{~b}$ & $3.33 \mathrm{a}$ & $13.33 \mathrm{bc}$ & $0 \mathrm{~b}$ \\
\hline Langra & $10 \mathrm{~d}$ & $0 \mathrm{c}$ & $90 a$ & $56.67 \mathrm{a}$ & $3.33 a$ & $30 a$ & $0 \mathrm{~b}$ \\
\hline Takia Sheikan & $36.67 \mathrm{~b}$ & 0c & $60 \mathrm{bc}$ & $0 \mathrm{c}$ & $0 \mathrm{a}$ & $10 \mathrm{bc}$ & $0 \mathrm{~b}$ \\
\hline Diwal & $13.33 \mathrm{~cd}$ & $0 \mathrm{c}$ & 83.33a & $30 \mathrm{~b}$ & $0 \mathrm{a}$ & 23.33ab & $0 \mathrm{~b}$ \\
\hline Sajikot & $13.33 \mathrm{~cd}$ & $10 \mathrm{bc}$ & 76.67ab & $36.67 b$ & $0 \mathrm{a}$ & $6.67 c$ & $0 \mathrm{~b}$ \\
\hline
\end{tabular}

Table 1: Percent incidence of fungal pathogen(s) isolated from wheat leaf samples of ten locations of Tehsil Havelian.

Means represented with different alphabets showed significant difference at $\mathrm{P} \leq 0.05$ in a column or row.

tive'eye spot' appearance (Figure $2 \mathrm{~F}$ and $2 \mathrm{G}$ ). Tan spot lesions appeared on both lower and upper leaf surface.

Colonies were fast growing, blackish brown in colour with black reverse and rarely whitish on PDA media (Figure 3B). Conidia are straight or lightly curved, cylindrical, with rounded apex the basal segment distinctly is cone shaped. Spore color varies from light to dark brown with 3-8 transvers or pseudosepta, spore vary in size 27.5-62.5 x 10 - $15 \mu \mathrm{m}$ (Figure 4E). The characteristics of Drechslera tritici repentis matched with those reported by $[13,14]$.

\section{Fusarium head blight/scab}

Fusarium head blight of wheat (FHB) isolated and identified in five sampling locations (Banda, Khokkar Maira, Langra, Diwal, Sajikot) of Tehsil Havelian (Table 1 and 2) among which the significantly highest fungal incidence i.e. $56.67 \%$ was recorded from location Langra and least from location Banda (3.33\%). Charecterisitc symptoms include premature bleaching of the diseased spikelets shortly after infection. On leaves small tan to brown lesions with yellow halos appeared. Seeds developed from the infected spikelets may be shriveled and chalky or white in appearance referred to as tombstone.

Colony on PDA was white pinkish with cottony surface (Figure 3C). Conidia were hyaline, large straight sickle shaped with 3-7 horizontal septa measuring $20-27.5$ x $5-7.5 \mu \mathrm{m}$. One end cell is often slightly bend (Figure $4 \mathrm{~F}$ ). The characteristics were similar to those reported by $[13,14]$.

\section{Black point}

Black point also called kernel smudge caused by Cladosporium herbarum and Curvularia lunata. Both fungi were isolated from sampling locations among which Banda, Khokkar Maira, Langra, Takia Sheikan, Diwal, Sajikot samples were found infected with Cladosporium herbarum with maximum \% incidence of $23.33 \%$ in locations Banda and Diwal while Curvularia lunata was isolated only from one location Pangran with \% incidence of $6.67 \%$ (Table 1 and 2). During sampling yellow lesions were observed on leaves and dark brown to black discoloration of pericarps of maturing wheat kernals.

Cladosporium herbarum formed low, thick powdery or velvety olivaceous-green to olivaceous-brown, reverse greenish black colonies on PDA (Figure 3D). Conidia were lemon shaped to cylindrical ellipsoidal with one septa, light brown to smoky brown in colour. One-celled, reaching 7.5-10 x2.5-5 $\mu \mathrm{m}$ (Figure 4G) These characteristics matched with those described by $[13,14]$.

Curvularia lunata colony appeared downy, velvety black, fluffy (Figure 3E). Conidia were smooth walled olivaceous brown, obvoid 


\begin{tabular}{|c|c|c|c|}
\hline Location & Disease(s) identified & Location & $\begin{array}{l}\text { Disease(s) } \\
\text { identified }\end{array}$ \\
\hline \multirow{3}{*}{$\begin{array}{l}\text { Sultan- } \\
\text { pur }\end{array}$} & Alternaria leaf blight & \multirow{5}{*}{$\begin{array}{l}\text { Khokkar } \\
\text { Maira }\end{array}$} & Leaf rust \\
\hline & Leaf rust & & $\begin{array}{l}\text { Fusarium head } \\
\text { blight/ scab }\end{array}$ \\
\hline & Tan spot/yellow spot & & $\begin{array}{c}\text { Alternaria leaf } \\
\text { blight }\end{array}$ \\
\hline \multirow{3}{*}{ Chamba } & Alternaria leaf blight & & Black point \\
\hline & Leaf rust & & $\begin{array}{c}\text { Tan spot/yellow } \\
\text { spot }\end{array}$ \\
\hline & Loose smut & \multirow{5}{*}{ Langra } & Leaf rust \\
\hline \multirow{4}{*}{ Jangran } & Leaf rust & & $\begin{array}{c}\text { Fusarium head } \\
\text { blight }\end{array}$ \\
\hline & Loose smut & & $\begin{array}{c}\text { Alternaria leaf } \\
\text { blight }\end{array}$ \\
\hline & Alternaria leaf blight & & Black point \\
\hline & Black point & & $\begin{array}{c}\text { Tan spot/yellow } \\
\text { spot }\end{array}$ \\
\hline \multirow{4}{*}{ Pangran } & Leaf rust & \multirow{3}{*}{$\begin{array}{c}\text { Takkia } \\
\text { sheikhan }\end{array}$} & $\begin{array}{c}\text { Alternaria leaf } \\
\text { blight }\end{array}$ \\
\hline & Loose smut & & Leaf rust \\
\hline & Alternaria leaf blight & & Black point \\
\hline & Black point & \multirow{4}{*}{ Diwal } & Leaf rust \\
\hline \multirow{5}{*}{$\begin{array}{l}\text { Banda } \\
\text { Subkhan }\end{array}$} & Alternaria leaf blight & & $\begin{array}{c}\text { Fusarium head } \\
\text { blight }\end{array}$ \\
\hline & Leaf rust & & $\begin{array}{c}\text { Alternaria leaf } \\
\text { blight }\end{array}$ \\
\hline & \multirow{3}{*}{ Black point } & & Black point \\
\hline & & \multirow[b]{2}{*}{ Sajjikot } & Leaf rust \\
\hline & & & $\begin{array}{c}\text { Fusarium head } \\
\text { blight }\end{array}$ \\
\hline
\end{tabular}

Table 2: Fungal diseases of wheat identified on the basis of field symptoms and pathogen characteristics among ten sampling locations of Tehsil Havelian, District Abbottabad in 2019.

to broadly club shaped and bend at subterminal cell with length 20-25 $\mu \mathrm{m}$ and width 7.5-10 $\mu \mathrm{m}$ having three septa. The subterminal cell larger than remaining cell (Figure $4 \mathrm{H}$ ). These characteristics matched with those reported by $[13,14]$.
Identification and Percent Incidence of fungi isolated from Maize foliar samples

Pathogen(s) from the infected foliar maize samples were isolated on PDA media and identified on the basis of macro and microscopic charecteristics with reference to mycological keys of Barnett and Hunter 1998, Eillis 1982. The fungi isolated were Bipolaris maydis, Curvularia lunata, Alternaria alternata and Colletotrichum graminicola. On the basis of pathogen identification four different diseases of maize crop (Sourthen leaf blight, Curvularia leaf spot, Alternaria leaf blight, Anthracnose leaf blight) prevailed in the Tehsil Havelian.

\begin{tabular}{|l|c|c|c|c|}
\hline \multirow{2}{*}{ Location } & \multicolumn{4}{|c|}{ \% incidence of isolated Fungi } \\
\cline { 2 - 5 } & $\begin{array}{c}\text { Bipolaris } \\
\text { maydis }\end{array}$ & $\begin{array}{c}\text { Curvularia } \\
\text { lunata }\end{array}$ & $\begin{array}{c}\text { Alternaria } \\
\text { alternata }\end{array}$ & $\begin{array}{c}\text { Colle- } \\
\text { totrichum } \\
\text { graminicola }\end{array}$ \\
\hline Sultanpur & $93.33 \mathrm{a}$ & $0 \mathrm{~d}$ & $6.67 \mathrm{e}$ & $43.33 \mathrm{abc}$ \\
\hline Chamba & $50 \mathrm{~cd}$ & $0 \mathrm{~d}$ & $93.33 \mathrm{a}$ & $0 \mathrm{~d}$ \\
\hline Jangra & $86.67 \mathrm{ab}$ & $10 \mathrm{~cd}$ & $3.33 \mathrm{e}$ & $33.33 \mathrm{~b}$ \\
\hline Pangran & $0 \mathrm{e}$ & $86.67 \mathrm{a}$ & $43.33 \mathrm{~cd}$ & $0 \mathrm{~d}$ \\
\hline $\begin{array}{l}\text { Banda } \\
\text { Subkhan }\end{array}$ & $70 \mathrm{bc}$ & $0 \mathrm{~d}$ & $10 \mathrm{e}$ & $60 \mathrm{a}$ \\
\hline $\begin{array}{l}\text { Khokkar } \\
\text { Maira }\end{array}$ & $53.33 \mathrm{~cd}$ & $3.33 \mathrm{~cd}$ & $33.33 \mathrm{~d}$ & $46.67 \mathrm{ab}$ \\
\hline Langra & $76.67 \mathrm{ab}$ & $0 \mathrm{~d}$ & $40 \mathrm{~cd}$ & $36.67 \mathrm{~b}$ \\
\hline $\begin{array}{l}\text { Takia } \\
\text { Sheikan }\end{array}$ & $93.33 \mathrm{a}$ & $26.67 \mathrm{~b}$ & $3.33 \mathrm{e}$ & $26.67 \mathrm{c}$ \\
\hline Diwal & $46.67 \mathrm{~d}$ & $16.66 \mathrm{bcd}$ & $70 \mathrm{~b}$ & $0 \mathrm{~d}$ \\
\hline Sajikot & $53.33 \mathrm{~cd}$ & $20 \mathrm{bc}$ & $56.67 \mathrm{bc}$ & $6.67 \mathrm{~d}$ \\
\hline
\end{tabular}

Table 3: Percent incidence of fungal pathogen(s) isolated from foliar samples of Maize in Tehsil Havelian.

Means represented with different alphabets showed significant difference at $\mathrm{P} \leq 0.05$ in a column or row.

\section{Sourthen corn leaf blight}

Southern corn leaf blight is one of major fungal disease of maize caused by fungus Bipolaris maydis also known as Cochliobolus heterostrophus in its teleomorph state (previously known as Drechslera maydis or Helminthosporium maydis) and it was observed in nine locations during sampling except in location Pangran (Table 3). The maximum \% incidence of $93.33 \%$ was recorded in samples of location Sultanpur and Takia Sheikan followed by 
location Jangra (86.67\%), however location Diwal showed least incidence (46.67\%) of Bipolaris maydis (Table 3). The characteristic disease symptoms observed on corn leaves at the time of sampling were brown coloured oblong, oval or diamond shaped lesions which with the passage of time became elongated and were confined by leaf veins. The length of lesions was up to $2-3 \mathrm{~cm}$ and their width was $2-6 \mathrm{~mm}$. Lesions were usually present on lower leaves and move towards the upper leaves (Figure 5A).

Bipolaris maydis produced light grey to black colour colony on PDA (Figure 6A). Conidia have 4 - 10 septations, spindle shaped brown color with tapering to round ends. A small, slightly papillate hilum was observed at the base of conidia. The size is $17.5-105 \mathrm{x}$ 7.5-17.5 $\mu \mathrm{m}$ (Figure 7A) The characteristics of Bipolar maydis were found very close with those described by $[13,14]$.

\section{Curvularia leaf spot}

Curvularia lunata the causual organism of Curvularia leaf spot was recorded in six locations during sampling with maximum \% incidence of $86.67 \%$ from location Pangran (Table 3) while in location Khokhar Maira only 3.33\% incidence of Curvularia lunata was recorded. The samples of locations Sultanpur, Chamba, Banda Subkhan and Langra did not found infected with Curvularia lunata (Table 3). At the time of sampling brown to tan lesions $0.5 \mathrm{~cm}$ in diameter were observed (Figure 5B). Lesions often have reddish brown margins and encircled by a yellow halo in the mid to upper canopy of maize crop.

Cultural characteristics of $C$. lunata include gray to grayish black colony on potato dextrose agar medium (Figure 6B). Microscopically conidia were clavate, three septate, basal and apical cell pale brown, central cell was darker and larger (Figure 7B). The conidia were variable in size $22.5-32.5 x$ 7.5-15um. The characteristics of Curvlaria lunata matched with those described by $[13,14]$.

\section{Alternaria leaf blight}

The Alternaria alternata causes Alternaria leaf blight or leaf spot of maize was isolated and identified in all ten locations of Tehsil Havelian with highest \% incidence of $93.33 \%$ from location Chamba followed by location Diwal in which \% incidence of Alternaria alternata was $70 \%$ (Table 3 and 4). The least incidence of $3.33 \%$ was recorded from locations Jangra and Takia Sheikan (Table 3). Lesions on maize leaf incited by Alternaria alternata observed at the time of sampling were small, oblong brown Lesions encircle by a yellow halo. As disease progresses, lesions merge into brown necrotic areas, which expand for some distance but are restricted by the leaf veins (Figure 5C).
Colony morphology of Alternaria alternata on potato dextrose agar at initial stage was light grey which then turned to dark green or blackish with white margins (Figure 6C). The conidia were variable in size, dark brown in colour, ovate to ellipsoidal, muriform with a short, cylindrical beak but were often beakless. Conidia showed 3 -6 transverse septa with no or one longitudinal septa (Figure 7C). They range in size from 20-52.5um x7.5-15um. The characteristics of Alternaria alternata matched with those described by $[13,14]$.
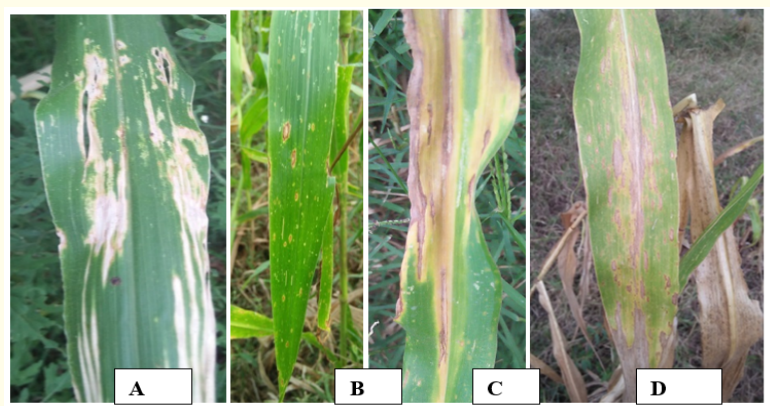

Figure 5: Characteristics symptoms of Sourthen leaf blight of maize (A); Curvularia leaf spot (B); Alternaria Leaf Blight (C); Anthracnose leaf blight (D) in maize field.
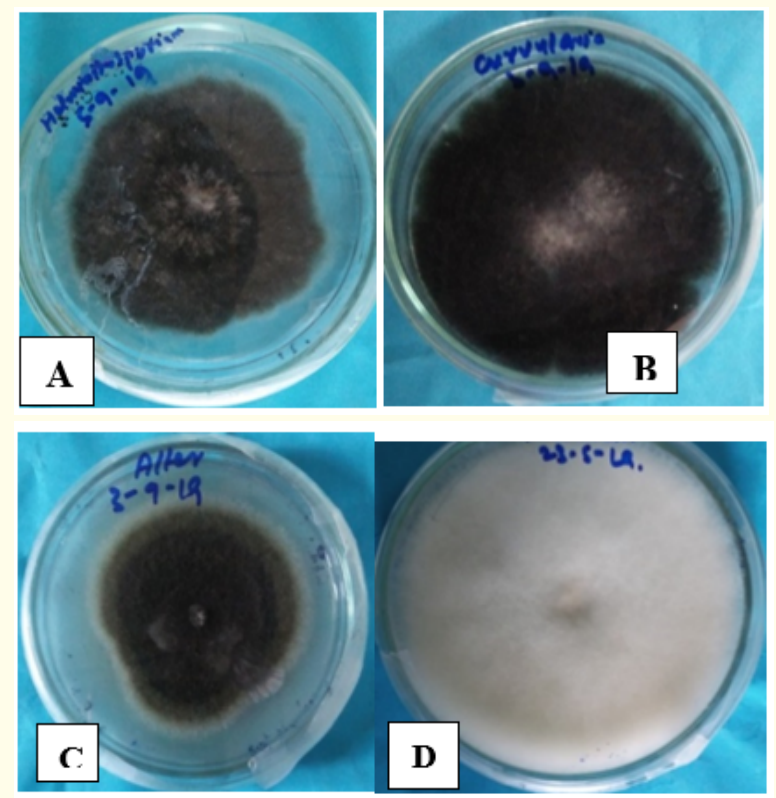

Figure 6: Pure cultures of fungi isolated from maize foliar samples on PDA after seven days of incubation at $25^{\circ} \mathrm{C}$; Colony of Bipolaris maydis (A); Curvularia lunata (B); Alternaria alternata (C); Colletotrichum graminicola (D). 


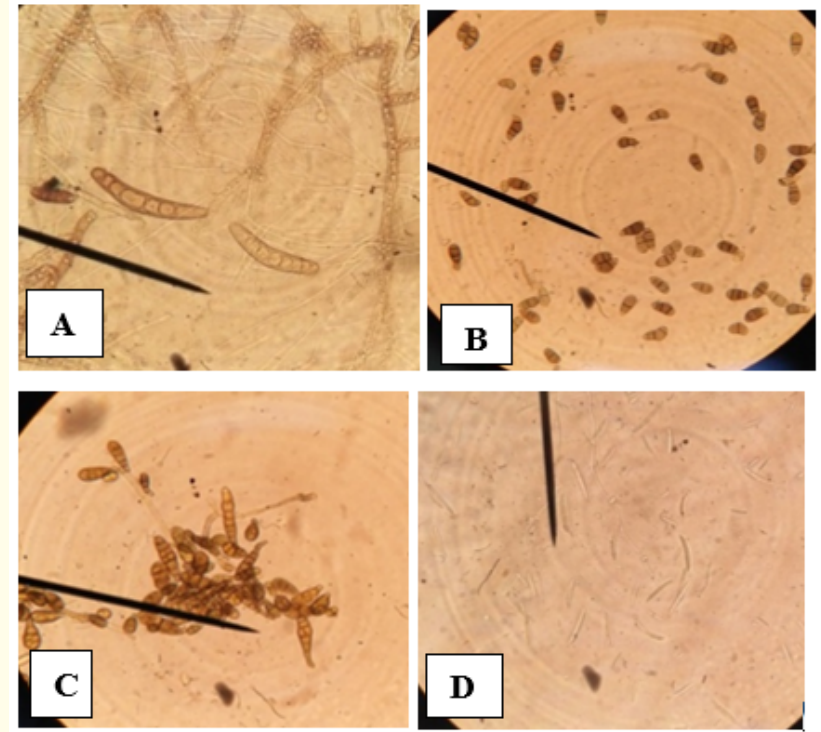

Figure 7: Conidia of Bipolaris maydis (A); conidia of Curvularia lunata (B); Conidia of Altenaria alternata (C); Conidia of Colletotrichum graminicola (D) at 400X magnification.

\section{Anthracnose leaf blight}

Anthracnose leaf blight of maize is important foliar disease caused by fungus Colletotrichum graminicola (anamorph) or Glomerella graminicola (teleomorph) was isolated and identified in seven sampling locations i.e Sultanpur, Jangran, Pangran, Banda subkhan, Khokkar maira, Langra, Takkia sheikhan and Sajikot with highest percent incidence (60\%) in location Banda subkhan while in location Sajjikot its incidence was 6.67\% (Table 3 and 4). The anthracnose leaf blight is characterized by oval to elongated brown lesions $(0.5-2 \mathrm{~cm})$ on leaves. These lesions gradually enlarge and become tan at the center surrounded by yellow or reddish brown zone these lesions fuse together covering all the leaf and entire leaf become blighted (Figure 5D). Anthracnose leaf blight initially showed lesions on lower leaves, as the disease boost spots move towards the upper leaves.

The colony colour of Colletotrichum graminicola on PDA was white (Figure 6D). Conidia were hyaline, non septate, falcate to fusiform, slightly curved and tapered toward the tips with an average length 12.5 - 45um and average width 2.5 to 7.5um (Figure 7D). The characteristics of Colletotrichum graminicola matched with those described by $[13,14]$.

\section{Single or mixed infection of wheat and maize crops}

Foliar samples of wheat and maize from of all ten sampling locations were found infected either with single or mixed infection.

\begin{tabular}{|c|c|c|c|}
\hline Location & $\begin{array}{c}\text { Disease(s) iden- } \\
\text { tified }\end{array}$ & Location & $\begin{array}{l}\text { Disease(s) } \\
\text { identified }\end{array}$ \\
\hline \multirow{3}{*}{ Sultanpur } & $\begin{array}{c}\text { Southern leaf } \\
\text { blight }\end{array}$ & \multirow{4}{*}{$\begin{array}{c}\text { Khokkar } \\
\text { Maira }\end{array}$} & $\begin{array}{c}\text { Southern leaf } \\
\text { blight }\end{array}$ \\
\hline & $\begin{array}{c}\text { Alternaria leaf } \\
\text { blight }\end{array}$ & & $\begin{array}{l}\text { Anthracnose } \\
\text { leaf blight }\end{array}$ \\
\hline & $\begin{array}{c}\text { Anthracnose leaf } \\
\text { blight }\end{array}$ & & $\begin{array}{c}\text { Alternaria leaf } \\
\text { blight }\end{array}$ \\
\hline \multirow{2}{*}{ Chamba } & $\begin{array}{c}\text { Alternaria leaf } \\
\text { blight }\end{array}$ & & $\begin{array}{c}\text { Curvularia leaf } \\
\text { spot }\end{array}$ \\
\hline & $\begin{array}{c}\text { Southern leaf } \\
\text { blight }\end{array}$ & \multirow{3}{*}{ Langra } & $\begin{array}{c}\text { Southern leaf } \\
\text { blight }\end{array}$ \\
\hline \multirow{4}{*}{ Jangran } & $\begin{array}{c}\text { Alternaria leaf } \\
\text { blight }\end{array}$ & & $\begin{array}{c}\text { Anthracnose } \\
\text { leaf blight }\end{array}$ \\
\hline & $\begin{array}{c}\text { Southern leaf } \\
\text { blight }\end{array}$ & & $\begin{array}{c}\text { Alternaria leaf } \\
\text { blight }\end{array}$ \\
\hline & $\begin{array}{c}\text { Anthracnose leaf } \\
\text { blight }\end{array}$ & \multirow{3}{*}{$\begin{array}{c}\text { Takkia } \\
\text { sheikhan }\end{array}$} & $\begin{array}{c}\text { Southern leaf } \\
\text { blight }\end{array}$ \\
\hline & $\begin{array}{c}\text { Curvularia leaf } \\
\text { spot }\end{array}$ & & $\begin{array}{c}\text { Curvularia leaf } \\
\text { spot }\end{array}$ \\
\hline \multirow{2}{*}{ Pangran } & $\begin{array}{c}\text { Alternaria leaf } \\
\text { blight }\end{array}$ & & $\begin{array}{l}\text { Anthracnose } \\
\text { leaf blight }\end{array}$ \\
\hline & $\begin{array}{c}\text { Curvularia leaf } \\
\text { spot }\end{array}$ & \multirow{3}{*}{ Diwal } & $\begin{array}{c}\text { Southern leaf } \\
\text { blight }\end{array}$ \\
\hline \multirow{6}{*}{$\begin{array}{l}\text { Banda } \\
\text { Subkhan }\end{array}$} & $\begin{array}{c}\text { Southern leaf } \\
\text { blight }\end{array}$ & & $\begin{array}{c}\text { Curvularia leaf } \\
\text { spot }\end{array}$ \\
\hline & $\begin{array}{c}\text { Anthracnose leaf } \\
\text { blight }\end{array}$ & & $\begin{array}{c}\text { Alternaria leaf } \\
\text { blight }\end{array}$ \\
\hline & \multirow{4}{*}{$\begin{array}{c}\text { Alternaria leaf } \\
\text { blight }\end{array}$} & \multirow{4}{*}{ Sajjikot } & $\begin{array}{c}\text { Southern leaf } \\
\text { blight }\end{array}$ \\
\hline & & & $\begin{array}{c}\text { Anthracnose } \\
\text { leaf blight }\end{array}$ \\
\hline & & & $\begin{array}{c}\text { Alternaria leaf } \\
\text { blight }\end{array}$ \\
\hline & & & $\begin{array}{c}\text { Curvularia leaf } \\
\text { spot }\end{array}$ \\
\hline
\end{tabular}

Table 4: Fungal diseases of maize identified on the basis of field symptoms and pathogenic characteristics among ten sampling locations of Tehsil Havelian, District Abbottabad in 2019.

Single infection percentage was found high as compared to mixed infections. For wheat among the ten locations 100\% single infection was observed in Sultanpur, Chamba, Jangra while the high percentage of mixed infection(s) were found in Langra (66.6\%) followed by Diwal and Sajjikot (43.33\%) (Table 5). Regarding maize all the ten locations showed single as well as mixed infections. Max- 
imum single infection percentage was observed in Diwal (66.66\%) followed by $63.33 \%$ in Sajjikot, Pangran, Jangran and, Khokkar maira, while minimum infection (50\%) was recorded in Sultanpur, Chamba and Langran. The highest percentage of mixed infection was observed in Langra i-e 50\% and low $33.33 \%$ was in locations Diwal, Khokkar maira, Pangran and Jangra (Table 6).

\begin{tabular}{|l|c|c|}
\hline \multicolumn{1}{|c|}{ Location } & $\begin{array}{c}\text { Single } \\
\text { infection }\end{array}$ & $\begin{array}{c}\text { Mixed/Multiple } \\
\text { infection }\end{array}$ \\
\hline Sultanpur & $100 \%$ & $0 \%$ \\
\hline Chamba & $100 \%$ & $0 \%$ \\
\hline Jangra & $100 \%$ & $0 \%$ \\
\hline Pangran & 96.66 & $3.33 \%$ \\
\hline Banda Subkhan & $63.33 \%$ & $23.33 \%$ \\
\hline Khokkar Maira & $70 \%$ & $26.66 \%$ \\
\hline Langra & $33.33 \%$ & $66.66 \%$ \\
\hline Takkia Sheikhan & $93.33 \%$ & $6.66 \%$ \\
\hline Diwal & $56.66 \%$ & $43.33 \%$ \\
\hline Sajikot & $56.66 \%$ & $43.33 \%$ \\
\hline
\end{tabular}

Table 5: Single and Mixed infection of wheat fungal pathogen(s) in Tehsil Havelian.

\begin{tabular}{|l|c|c|}
\hline \multicolumn{1}{|c|}{ Location } & Single infection & $\begin{array}{c}\text { Mixed/Multiple } \\
\text { infection }\end{array}$ \\
\hline Sultanpur & $50 \%$ & $46.66 \%$ \\
\hline Chamba & $50 \%$ & $46.66 \%$ \\
\hline Jangra & $63.33 \%$ & $33.33 \%$ \\
\hline Pangran & $63.33 \%$ & $33.33 \%$ \\
\hline Banda Subkhan & $60 \%$ & $40 \%$ \\
\hline Khokkar Maira & $63.33 \%$ & $33.33 \%$ \\
\hline Langra & $50 \%$ & $50 \%$ \\
\hline Takkia Sheikhan & $53.33 \%$ & $46.66 \%$ \\
\hline Diwal & $66.66 \%$ & $33.33 \%$ \\
\hline Sajjikot & $63.33 \%$ & $36.66 \%$ \\
\hline
\end{tabular}

Table 6: Single and Mixed infection of fungal pathogen(s) of maize crop of Tehsil Havelian.

\section{Discussion}

There are many factors involved in crop yield losses in which diseases play a significant role. Fungal pathogens not only damage crops but also causes major losses in food production. In the present study a number of fungal pathogens were isolated from foliar samples of Wheat and Maize.

Puccinia recondita causes leaf rust is most common wheat rust and is most prevalent wheat disease in the sampling areas of Tehsil Havelian (Table 1). The fungus is an obligate parasite and produces orange coloured uredia on wheat leaves as most predominant characteristic which with time change color from orange to black (telia) (Figure 2A,B). Similar field symptoms were reported by [15-17] who concluded that leaf rust is characterized by uredinial stage.

Weather plays a key role in development of leaf rust. Moderate nights and warm days are ideal for rust development. Its incidence percentage was higher in location Sultanpur and it may due to the fact that this area falls in the mild to warmer part of Tehsil Havelian. $[18,19]$ reported that wheat leaf rust is favored by three important weather factors that are moisture, temperature and wind. Temperature affects spore germination, infection, and host resistance. The relative humidity played an important role in the penetration of fungus haustorium because it makes the leaf tender due to moisture content.

Ustilago tritici the causal organism of loose smut of wheat was detected in only four sampling locations i.e Chamba, Jangra, Pangran and Sajjikot of Tehsil Havelian with maximum incidence $23.33 \%$ in Jangra (Table 1). Loose smut is seed borne fungal disease and the fungus continues to survive within the embryo of infected wheat seed as dormant mycelia and spread to next crop through infected seed [20]. In this location at the time of sampling wheat crop was at grain filling stage and showed heads covered with black powdery masses instead of healthy grains (Figure 2C). The possible reason for this high incidence in Jangra samples was that the farmers grow uncertified seed.

Alternaria leaf blight in wheat is the most prevalent fungal disease among the sampling areas (Table 1). This fungus is both soilborne and seedborne, however, seed borne transmission can be the most likely mechanism in the sampling locations because the local farmers commonly used uncertified seed. Alternaria triticina produced black to brown colonies with smooth and entire margins on PDA (Figure 3A). [21] reported that Alternaria colonies on potato dextrose agar are discrete or effuse, dark blackish to black with smooth boarders. 
Drechslera tritici repentis caused tan spot of wheat was isolated from samples of three locations Sultanpur, Khokkar maira and Langra with very low \% incidence i.e. 3.33\% (Table 1). The spores germination of Drechslera tritici repentis is favoured by rain fall, significant dew and high canopy humidity with wide temperature range above $10^{\circ} \mathrm{C}$. The infection spreads in the form of conidia which dispersed by wind $[22,23]$. In these locations heavy rainfall with thunderstorms occured in March to April which favors the tan spot. The fungus formed characteristic oval shaped lesions surrounded by a yellow ring on both upper and lower surfaces of leaves in wheat (Figure 2F,G) which were similar to the symptoms reported by [24-26].

The Fusarium graminearum causes Fusarium head blight in wheat was isolated in five locations (Table 3) with high\% incidence percentage $(56.67 \%)$ in location langra. The sampling was done in April and during this month temperature in langra was warm to cool, rainfall occured in this month. [27] reported that FHB infection is favored by high relative humidity (>90\%) and moderately warm temperatures (between 15 to $30^{\circ} \mathrm{C}$ ). These conditions present before, during, and after flowering favor inoculum production, floret infection, and colonization of developing grains. $(28,29)$ reported that Fusarium is a soilborne fungus its Conidia overwinter in soil or in crop residue in the field and serves as inoculum for next season crop spread.

Fusarium graminearum showed tan to brown lesions with yellow halos on leaves. [30] reported that the leaves of infected plants lose turgidity, turn light green to greenish-yellow to brown, and finally collapse and die. In culture it showed white cottony colonies on PDA media. Conidia were hyaline, large straight sickle shaped with 3-5 horizontal septa (Figure 4F). Similar cultural characteristics were described by $[13,14,31]$.

Black point of wheat is a seedborne disease and is caused by multiple fungi among which Cladosporium herbarum and Curvularia lunata were detected in sampling locations (Table 1). No distinguishing foliar symptoms were observed except tan or yellow dull colour instead of healthy green colour. Their presence in leaf samples may be due to the infected seed used or may be due to soil infestation in which crops were planted. The farmers of these locations usually use uncertified seed which can be the main reason for prevalence of many seedborne fungal diseases in Tehsil Havelian. Sampling was done during March and April and at this time en- vironmental condition was wet which favors the disease at grain filling stage. On PDA media Cladosporium herbarum showed green to greenish black colony (Figure 3D), while Curvularia lunata produced velvety black colonies (Figure $3 \mathrm{E}$ ), same colony characteristics were described by [32], respectively.

In maize crop four fungal pathogens were isolated and identified from foliar samples (Table 3). Bipolaris maydis is fungal pathogen which causes sourthern corn leaf blight in maize was found in nine locations with maximum percent incidence $93.33 \%$ in location Sultanpur. Temperature and amount of rainfall is critical in dissemination and survival of Bipolaris maydis. The sampling was done in August and monsoon rains occurred during this month. [33] reported that high humidity with low temperature and cloudy weather favours southern corn leaf blight along with heavy dew on host plant also increase disease severity. Once plant is infected it will develop oval, diamond shaped lesions on their leaf surfaces. Bipolar maydis produced light grey to black colour colony on PDA (Figure 5A). [34] also reported of black to grey coloured coloy of Bipolaris maydis on PDA.

Curvularia lunata is fungal pathogen in maize causing Curvularia leaf spot and during sampling it was isolated from six locations with maximum incidence $86.67 \%$ in location Pangran (Table $3)$. Characteristic disease symptoms are tan lesions $(0.5 \mathrm{~cm})$ with reddish brown boarders (Figure 5B) similar symptoms are also reported by [35]. Pathogen remains viable in crop debris which is most important source of infection. Spores spread by wind or splash with water and infect maize in wide temperature range. During continous wet period large number of conidia formed in the disease lesions, blown onto other maize plants to form new infection.

Alternaria alternata caused Alternaria leaf blight in maize and showed small lesions on infected maize leaves (Figure $5 \mathrm{C}$ and Table 3 and 4) was isolated from nine sampling locations (Table 4). Majority of the farmers used uncertified seed which can be a possible reason of its prevalence because Alternaria is a seedborne fungus and overwinters as dormant mycelium in the seed.

Colletotrichum graminicola causes anthracnose leaf blight in maize is isolated in six locations (Table 3) with highest percent incidence $60 \%$ in location Banda subkhan. The sampling was done 
in October and the environmental condition of Banda subkhan was moderate, nights are cool as compared to days which was favorable for infection of Anthracnose leaf blight. Further at this time the maize crop was near to maturity in this location. The anthracnose leaf blight is characterized by oval to elongated brown lesion on leaves $(0.5-2 \mathrm{~cm})$ (Figure 5D). Similar characteristic symptoms of Anthracnose leaf blight of maize were described by [36]. Its colony and conidial characters (Figure 6D and 7D) resembles to those described by $[13,14,37]$, who concluded that the conidia of $C$. graminicola are falcate shaped slightly curved and show no septations.

All foliar samples of wheat and maize crop collected from ten locations of Tehsil Havelian were found infected either singly or with mixed infections (Table 5 and 6). It may due to that mostly farmers of Tehsil Havelian have land holdings of less than one hectare, they do not purchase certified disease free seed from authentic seed companies and rely on their own produce as seed sources for next season crop, Further the farmers do not use any fungicide spray as preventive control measures.

\section{Conclusions and Recommendations}

It is concluded from present study that the wheat and maize crops of Tehsil Havelian, District Abbottabad were found infected with fungal diseases either singly or mixed infection. From wheat samples six fungal pathogens Puccinia recondita, Ustilago tritici, Alternaria triticina, Drechslera tritici repentis, Fusarium gramineraum, Cladosporium herbarum and Curvularia lunata and in maize four pathogens Helminthosporium maydis, Curvularia lunata, Alternaria alternata and Colletotrichum graminicola were isolated. These diseases are a great threat to future yield production.

There is need of further research work on molecular level to identify the specific fungal isolates present in the study area. Majority of the farmers have little knowledge about fungal diseases and their efficient control therefore it is recommended that farmers should be educated through trainings and seminars etc. for proper disease control measures and the use of healthy certified seed for their crop production.

\section{Bibliography}

1. Pakistan Economic Survey. "Finance Division Government of Pakistan". 2018-2019.

2. Crop statistics Khyber Pakhtunkhwa). Government of Khyber Pakhtunkhwa crop reporting services Agriculture, Livestock, and Coop: Deptt (2018-2019).

3. Figueroa M., et al. "A review of wheat diseases-a field perspective". Molecular Plant Pathology 19.6 (2018): 1523-1536.

4. Singh DP., et al. "Losses caused due to leaf blight in wheat in different agro climatic zones of India”. Plant Diseases Research 17.2 (2002): 313-317.

5. Asad S., et al. "Pathogenic diversity in Bipolaris sorokiniana isolates collected from different wheat growing areas of the Punjab and NWFP of Pakistan". Pakistan Journal of Botany 39.6 (2007): 2225-2231.

6. Ali S., et al. "First report of tan spot on wheat in Pakistan". Plant Disease 85.9 (2001): 1031.

7. Iram S and I Ahmad. "Prevalence and disease incidence of foliar blight of wheat in rice wheat cropping system of Punjab". Pakistan Journal of Botany 37.4 (2005): 973-980.

8. Ahmed S., et al. "Determination of Efficacy of cypermethrin, regent and carbofuran against Chilo partellus Swin. and biochemical changes following their application in maize plants". International Journal of Agriculture and Biology 5.1 (2003): 30-35.

9. Chhokar RS. "Development and use of herbicides". Pesticides Information 27 (2001): 25-27.

10. Kump KI., et al. "Genomewide association study of quantitative resistance to southern leaf blight in maize nested association mapping population". Nature Genetics 43 (2011): 163-168.

11. Farhan A., et al. "Accumulation of desirable alleles for southern leaf blight (SLB) in maize (Zea mays L.) under the epiphytotic of Helminthosporium maydis". Australian Journal of Crop Science 6.8 (2012): 1283-1289.

12. Zehnder G. "Overview of Monitoring and Identification Techniques for Insect Pests". Clemson University. Cooperative Extension System, USA (2010).

13. Barnett HL and BB Hunter. "Illustrated genera of imperfect fungi”. 4th Edition, American Phytopathological Society. (1998): 218.

14. EllisMB. "Dematiaceous hyphomycetes". Common wealth Mycological institute Kew, Surrey, England (1982): 524. 
15. Baka ZAM and S Rabei. "Morphology of uredinia and urediniospores of seven Puccinia species attacking Poaceae in Egypt". Egyptian Journal of Botany 3 (2013): 407-421.

16. Bolton MD., et al. "Wheat leaf rust caused by Puccinia triticina". Molecular Plant Pathology 9 (2008): 563-575.

17. Prescott JM., et al. "Wheat diseases and pests: a guide for field identification". CIMMYT, Mexico (1986): 135.

18. Wiik L and T Ewaldz. "Impact of temperature and precipitation on yield and plant diseases of winter wheat in southern Sweden 1983-2007". Crop Protection 28 (2009): 952-962.

19. Devallavieille-Pope C., et al. "Preinoculation effects of light quantity on infection efficiency of Puccinia striiformis and P. triticina on wheat seedlings". Phytopathology 92.12 (2002): 1308-1314.

20. Khazaei F., et al. "Seed borne disease in formal and informal wheat (Triticum aestivum L.) seed production systems in three provinces of Iran". International Journal of Biosciences 5 (2014): 381-388.

21. Anashosur KH. "Alternaria triticina Descriptions of Pathogenic Fungi and Bacteria". Willingford, UK: CAB International No 583 (1978).

22. Wegulo SN., et al. "Tan spot of wheat. Neb Guide”. Univ. of Nebraska Lincoln Extension, Institute of Agri. and Natural Resources. (2012) 4 .

23. Wiese MV. "Compendium of Wheat Diseases". The American Phytopathological Society, St. Paul, MN, USA (1987).

24. Moreno MV and AE. Perelló. "Occurrence of Pyrenophora tritici-repentis Causing Tan Spot in Argentina". Management of Fungal Plant Pathogens (2010): 275.

25. Jørgensen LN and LV Olsen. "Control of tan spot (Dreschlera tritici-repentis) using cultivar resistance, tillage methods and fungicides". Crop Protection 26 (2007): 1606-1616.

26. Carmona MA., et al. "Tan spot of wheat caused by Drechslera tritici-repentis: Dectection, Transmission and Control in wheat seed". Cereal Research Communications 34 (2006): 1043-1049.
27. Schmale DG and GC Bergstrom. "Fusarium head blight in wheat". The Plant Health Instructor. The American Phytopathological Society USA (2010).

28. Mathre DE. "Compendium of Barley Diseases". 2nd Edition. APS Press, St. Paul, MN (1997): 90.

29. Parry DW., et al. "Fusarium ear blight (scab) in small grain cereals-a review”. Plant Pathology 44 (1995): 207-238.

30. Nalini S and R Parthasarathi. "Optimization of rhamnolipid biosurfactant production from Serratia rubidaea SNAU02 under solid-state fermentation and its biocontrol efficacy against Fusarium wilt of eggplant". Annals of Agricultural Science 16.2 (2018): 108-115.

31. Picco M., et al. "Aflatoxin B1 and fumosin B1 in mixed cultures of Aspergillus flavus and Fusarium proliferatum on maize". Natural Toxins 7.6 (1999): 331-336.

32. Aneja KR. "Experiments in microbiology, plant pathology and biotechnology". New Age International Limited. New Delhi (2003): 245-275.

33. Singh R and R P Srivastava. "Southern Corn Leaf Blight-an important disease of maize: an extension fact sheet". Indian Research Journal of Extension Education 12.2 (2016): 324-327.

34. Pal ISHAR., et al. "Characterization of Bipolaris maydis isolates of different maize cropping zones of India". Indian Phytopathology 68.1 (2015): 63-66.

35. Teddy GA., et al. "First report of Curvularia leaf spot of corn caused by Curvularia lunata in united states". Plant Health Progress 19 (2018): 140-142.

36. Bergstrom GC and RL Nicholson. "The biology of corn anthracnose: knowledge to exploit for improved management". Plant Disease 83.7 (1999): 596-608.

37. Sanz-Martín JMV., et al. "First report of Colletritichum graminicola causing Maize Anthracnose Stalk Rot in the Alentejo Region, Portugal”. Plant Disease 100.3 (2016): 648.

\section{Volume 5 Issue 8 August 2021 (C) All rights are reserved by Zishan Gul., et al.}

